\title{
Freshwater fish fauna of the Ashambu Hills landscape, southern Western Ghats, India, with notes on some range extensions
}

\author{
Robin Kurian Abraham ${ }^{1}$, Nachiket Kelkar ${ }^{2} \&$ A. Biju Kumar ${ }^{3}$ \\ 1,2 TC 11/1123, YMR Junction, Kowdiar P.O., Nanthencode, Thiruvananthapuram, Kerala 695003, India \\ ${ }^{3}$ Department of Aquatic Biology and Fisheries, University of Kerala, Kariavattom, Thiruvananthapuram, Kerala 695581, India \\ Email: ${ }^{1}$ robinabrahamf50@gmail.com, ${ }^{2}$ rainmaker.nsk@gmail.com (corresponding author), ${ }^{3}$ bijupuzhayoram@gmail.com
}

Date of publication (online): 26 March 2011 Date of publication (print): 26 March 2011 ISSN 0974-7907 (online) | 0974-7893 (print)

Editor: K. Rema Devi

\section{Manuscript details:}

Ms \# 02528

Received 27 July 2010

Final received 18 December 2011

Finally accepted 03 March 2011

Citation: Abraham, R.K., N. Kelkar \&A.B. Kumar (2011). Freshwater fish fauna of the Ashambu Hills landscape, southern Western Ghats, India, with notes on some range extensions. Journal of Threatened Taxa 3(3): 1585-1593.

Copyright: (c) Robin Kurian Abraham, Nachiket Kelkar \&A. Biju Kumar 2011. Creative Commons Attribution 3.0 Unported License. JoTT allows unrestricted use of this article in any medium for non-profit purposes, reproduction and distribution by providing adequate credit to the authors and the source of publication.

For Author Details, Author Contribution and Acknowledgements: See end of the article.

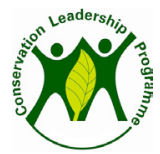

FAUNA \& FLORA

INTERNATIONAL

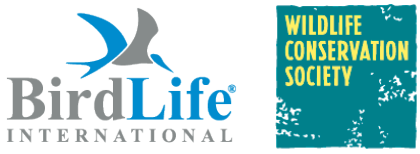

CONSERVATION INTERNATIONAL

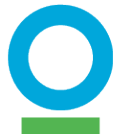

Abstract: A systematic, updated checklist of freshwater fish species of the west-flowing drainages of the Ashambu (Agasthyamala) Hills landscape in the southern Western Ghats of Kerala, India is provided, with notes on occurrence, status and ecology of endemic and threatened species. The checklist incorporates information from a review of taxonomic, exploratory and ecological literature concerning the area. A total of 103 species have been reported from the landscape, with 25 endemic to the Western Ghats. Range extension of four species, viz. Garra mcclellandi, G. hughi, Hypselobarbus jerdoni and Puntius mahecola is reported from the Ashambu Hills landscape.

Keywords: Ashambu Hills, endemics, fish diversity, Garra, Puntius, Hypselobarbus, range extension, threatened species, Western Ghats.

\section{INTRODUCTION}

The Western Ghats mountain range extends along the west coast of India and is crisscrossed with streams, which form the headwaters of several major rivers providing water to the plains of peninsular India. The Ghats represent a globally critical ecosystem and biodiversity hotspot (Myers et al. 2000). Freshwater fish diversity is very high, with around 288 species and a high rate of endemism ( $>50 \%$ ) (Daniels 2002; Dahanukar 2004). The southern Western Ghats that comprise the Ashambu (Agasthyamala) Hills landscape in Kerala form a biogeographically unique ecoregion (Nair 1991). As with several other taxa, this region is very rich in fish species diversity and endemism (Bossuyt et al. 2004).

The west flowing rivers south of the Shenkottah/Ariyankavu pass have not been extensively surveyed for fish diversity. Most surveys to date have been conducted either in easily accessible sites or in limited localities along individual rivers. In this paper we provide a systematic, updated checklist of freshwater fishes across five important rivers of Kollam and Thiruvananthapuram districts of Kerala, namely, Kallada, Ithikkara, Vamanapuram, Karamana and Neyyar, based on the available literature, secondary data and field-sampling along these rivers in the Ashambu Hills landscape. Habitat preferences and anthropogenic threats have been listed for each species included in the checklist, along with ecological and threat information. This can facilitate the identification of conservation priorities for freshwater fish diversity in the region. 


\section{MATERIALS AND METHODS}

The Kerala part of the Ashambu Hills covers the region southward from the Shenkottah/Ariyankavu Pass with three wildlife sanctuaries (WLS) and two reserve forests (RF) and is contiguous with the Kalakad-Mundanthurai Tiger Reserve (KMTR) to the east, in Tamil Nadu (Fig. 1). The Kallada, Ithikkara, Vamanapuram, Karamana and Neyyar are the main rivers in this landscape, that, with the exception of Ithikkara (origin at $240 \mathrm{~m}$ ), originate at elevations above $1500 \mathrm{~m}$ from wildlife sanctuaries or semiprotected reserve forests (Basak et al. 1995). These rivers proceed westward to meet the Arabian Sea, passing through a land-use gradient with midland areas dominated by rubber plantations and a lowland matrix of coconut/mixed-garden/paddy cultivation and rural to semi-urban/urban areas. The study was conducted from May 2009 to June 2010.

A preliminary checklist of fish species was prepared based on an exhaustive review of published literature, field guides, ecological studies, short notes and reports, taxonomic assessments and previous checklists from here and neighbouring regions (Silas 1951; Menon 1987; Jayaram 1981, 1991, 2010; Pethiyagoda 1994; Devi et al. 1996, 2005; Tekriwal \& Rao 1999; Sheeba
1999; Arunachalam 2000; Biju et al. 2000; Martin et al. 2000; Cherian et al. 2001; Daniels 2002; Bhat 2003, 2004; Easa \& Shaji 2003; Dahanukar et al. 2004; Thomas 2004; Raagam \& Devi 2004; Pethiyagoda \& Kottelat 2005a; Raghavan et al. 2007, 2008; Johnson \& Arunachalam 2009; Eschemeyer \& Fong 2010). This checklist includes 103 fish species belonging to 53 genera and 24 families (Table 1). Taxonomic treatment is based on Eschmeyer \& Fong (2010) and Jayaram (2010).

For primary data collection, 20 sampling locations were selected across the five rivers along the southern Western Ghats (Fig. 1), with uniform coverage of highland, midland and lowland areas. Sampling locations represented four broad land-use types (wildlife sanctuary/reserve forest, rubber plantation, coconut plantation/mixed-garden/paddy, semi-urban/ urban area). Sites at higher elevations and coastal areas were randomly surveyed to record restricteddistribution endemics or occasional estuarine/marine species. The fish surveys and identification were carried out through non-destructive sampling by using sampling methods suited to the nature of river course, stream order, flow, presence of aquatic vegetation and local human disturbance. Visual surveys, cast nets, gill-nets and hooks and lines were used to sample fish

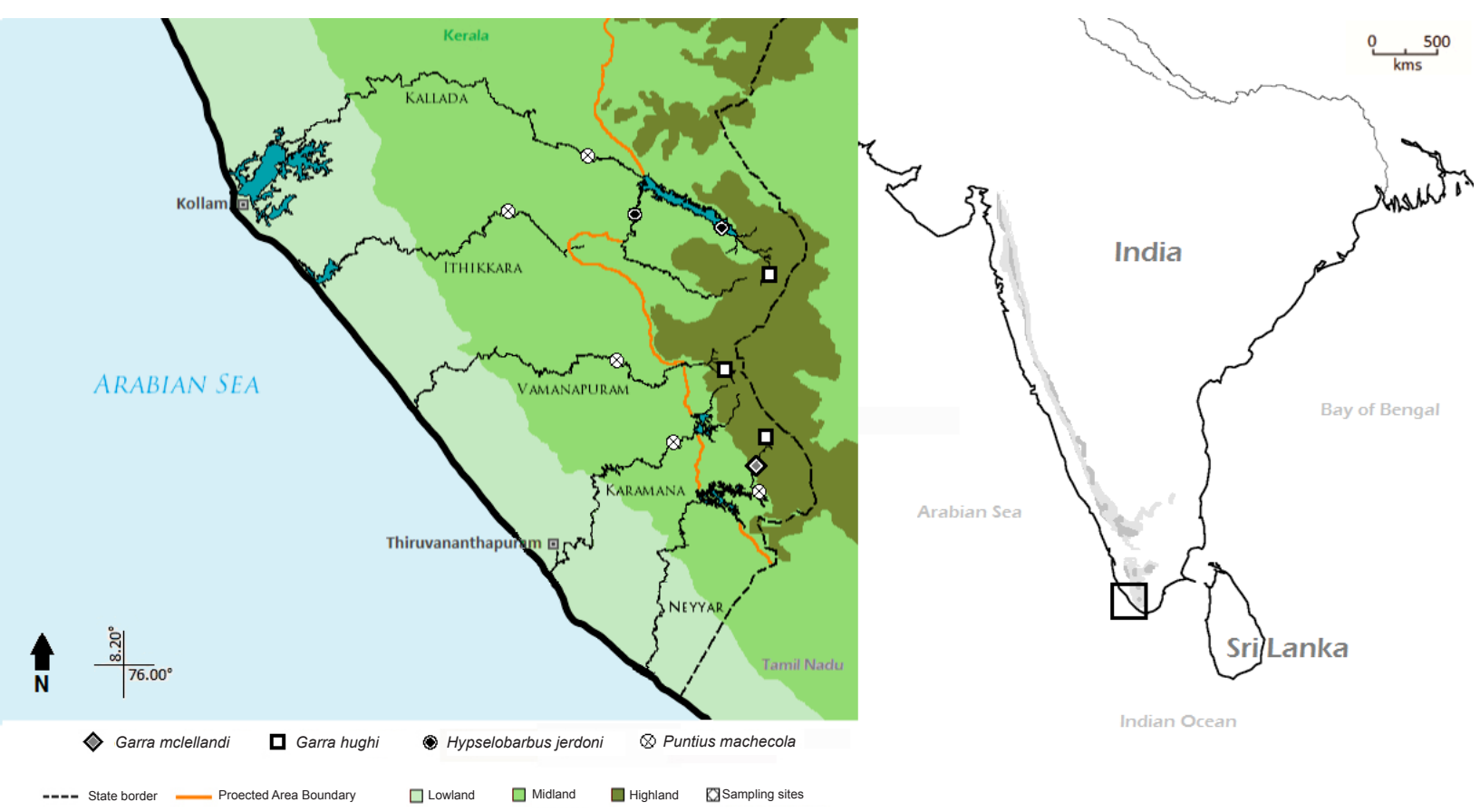

Figure 1. Map showing study area with locations indicated, where species' range extension were recorded in the Ashambu Hills (๑ Robin Abraham) 
Table 1. An annotated checklist of freshwater fish species known from the Ashambu Hills landscape. This checklist is derived from previous literature and updated by species sampled during our study (species for which preferred habitat, elevation range and occurrence are mentioned).

\begin{tabular}{|c|c|c|c|c|}
\hline Species & Threats & $\begin{array}{c}\text { Preferred } \\
\text { Habitat }\end{array}$ & $\begin{array}{c}\text { Elevation } \\
\text { Range }\end{array}$ & Occurrence in Rivers \\
\hline \multicolumn{5}{|l|}{ Ambassidae } \\
\hline Chanda nama Hamilton & $\mathrm{HL}$ & $\mathrm{Ru}$ & $\mathrm{m}$ & KLD \\
\hline Parambassis dayi ${ }^{+}$Bleeker & $\mathrm{HL}$ & & & \\
\hline Parambassis thomassi ${ }^{+}$(Day) & HL, DY, IN & $\mathrm{Ru}$ & $\mathrm{m}$ & KLD, VAM, KAR, NEY \\
\hline Pseudambassis ranga (Hamilton-Buchanan) & $\mathrm{HL}$ & $\mathrm{Ru}$ & $\mathrm{m}$ & KLD, KAR, NEY \\
\hline \multicolumn{5}{|l|}{ Anabantidae } \\
\hline Anabas testudineus Bloch & $\mathrm{HL}, \mathrm{IN}, \mathrm{DY}$ & & & \\
\hline \multicolumn{5}{|l|}{ Anguillidae } \\
\hline Anguilla bengalensis Gray & $\mathrm{HL}$ & $\mathrm{Ru}, \mathrm{PI}$ & $\mathrm{I}, \mathrm{m}, \mathrm{h}$ & KLD, ITK, VAM, KAR, NEY \\
\hline Anguilla bicolor McClelland & $\mathrm{HL}$ & & & \\
\hline \multicolumn{5}{|l|}{ Aplocheilidae } \\
\hline Aplocheilus lineatus (Valenciennes) & $\mathrm{HL}$ & $\mathrm{PI}$ & $\mathrm{I}, \mathrm{m}$ & KLD, ITK, VAM, KAR, NEY \\
\hline Aplocheilus blockii + (Arnold) & $\mathrm{HL}$ & $\mathrm{PI}$ & $\mathrm{m}$ & NEY \\
\hline \multicolumn{5}{|l|}{ Bagridae } \\
\hline Batasio travancorica + Hora \& Law & HL, DY & & & \\
\hline Horabagrus brachysoma + (Gunther) & HL, DY & $\mathrm{PI}$ & $\mathrm{I}, \mathrm{m}$ & KLD, KAR, NEY \\
\hline Mystus armatus Day & $\mathrm{HL}$ & & & \\
\hline Mystus bleekeri (Day) & $\mathrm{HL}$ & $\mathrm{PI}$ & $\mathrm{m}, \mathrm{h}$ & NEY \\
\hline Mystus cavasius Hamilton-Buchanan & $\mathrm{HL}$ & & & \\
\hline Mystus keletius (Valenciennes) & $\mathrm{HL}$ & & & \\
\hline Mystus malabaricus + (Jerdon) & HL, DY & $\mathrm{PI}$ & $\mathrm{m}, \mathrm{h}$ & KLD, ITK, VAM, KAR, NEY \\
\hline Mystus montanus Jerdon & $\mathrm{HL}$ & & & \\
\hline Mystus oculatus Valenciennes & $\mathrm{HL}$ & $\mathrm{Ru}, \mathrm{PI}$ & $\mathrm{m}$ & NEY \\
\hline Mystus vittatus Bloch & $\mathrm{HL}$ & & & \\
\hline \multicolumn{5}{|l|}{ Balitoridae } \\
\hline Bhavania australis + Jerdon & $\mathrm{HL}$ & $\mathrm{Ra}$ & $\mathrm{h}$ & KLD \\
\hline Travancoria jonesi ${ }^{+}$Hora & $\mathrm{HL}$ & $\mathrm{Ra}, \mathrm{Ri}$ & $\mathrm{h}$ & KLD, VAM \\
\hline Nemacheilus denisoni+ Day & $\mathrm{HL}$ & & & \\
\hline Nemacheilus pulchellus + Day & $\mathrm{HL}$ & & & \\
\hline Nemacheilus triangularis + Day & $\mathrm{HL}$ & $\mathrm{Ra}, \mathrm{Ru}, \mathrm{Ri}$ & $\mathrm{m}, \mathrm{h}$ & KLD, VAM, KAR, NEY \\
\hline \multicolumn{5}{|l|}{ Cobitidae } \\
\hline Pangio goaensis Tilak & $\mathrm{HL}$ & & & \\
\hline Lepidocephalichthys thermalis (Valenciennes) & $\mathrm{HL}$ & $\mathrm{Ra}, \mathrm{Ru}, \mathrm{Ri}$ & $\mathrm{m}, \mathrm{h}$ & KLD \\
\hline \multicolumn{5}{|l|}{ Belonidae } \\
\hline Xenentodon cancilla Hamilton-Buchanan & HL, DY & $\mathrm{Ru}, \mathrm{PI}$ & $\mathrm{I}, \mathrm{m}$ & KLD, ITK, VAM, KAR, NEY \\
\hline \multicolumn{5}{|l|}{ Channidae } \\
\hline Channa gachua Bloch \& Schneider & HL, DY, IN & $\mathrm{Ru}, \mathrm{PI}$ & $\mathrm{I}, \mathrm{m}$ & VAM \\
\hline Channa marulius Hamilton-Buchanan & HL, DY, IN & $\mathrm{Ru}, \mathrm{PI}$ & $\mathrm{I}, \mathrm{m}$ & VAM, KLD \\
\hline Channa striata (Bloch) & HL, DY & $\mathrm{Ru}, \mathrm{PI}$ & $\mathrm{I}, \mathrm{m}$ & KLD, ITK, VAM, KAR, NEY \\
\hline Channa diplogramma ${ }^{+, \wedge}$ (Day) & HL, DY, OF & $\mathrm{Ru}, \mathrm{PI}$ & $\mathrm{m}$ & KLD \\
\hline \multicolumn{5}{|l|}{ Cichlidae } \\
\hline Etroplus maculatus (Bloch) & HL, DY & $\mathrm{Ru}, \mathrm{PI}$ & $\mathrm{I}, \mathrm{m}$ & KLD, ITK, VAM, KAR, NEY \\
\hline Etroplus suratensis (Bloch) & HL, DY & $\mathrm{Ru}, \mathrm{PI}$ & I & KLD, ITK, VAM, KAR, NEY \\
\hline
\end{tabular}




\begin{tabular}{|c|c|c|c|c|}
\hline Species & Threats & $\begin{array}{c}\text { Preferred } \\
\text { Habitat }\end{array}$ & $\begin{array}{c}\text { Elevation } \\
\text { Range }\end{array}$ & Occurrence in Rivers \\
\hline Oreochromis mossambicus (Peters) & - & $\mathrm{Ru}, \mathrm{PI}$ & $\mathrm{I}, \mathrm{m}$ & NEY, KLD \\
\hline \multicolumn{5}{|l|}{ Clariidae } \\
\hline Clarias dussumieri ${ }^{+}$Valenciennes & $\mathrm{HL}, \mathrm{OF}, \mathrm{IN}$ & $\mathrm{PI}$ & $\mathrm{m}$ & KLD, NEY \\
\hline Heteropneustes fossilis Bloch & HL, DY & $\mathrm{PI}$ & $\mathrm{I}, \mathrm{m}$ & NEY \\
\hline \multicolumn{5}{|l|}{ Clupeidae } \\
\hline Dayella malabarica + (Day) & $\mathrm{HL}$ & $\mathrm{Ru}$ & $\mathrm{m}$ & KLD \\
\hline \multicolumn{5}{|l|}{ Cyprinidae } \\
\hline Laubuca dadyburjori + Menon & $\mathrm{HL}$ & & & \\
\hline Salmophasia boopis + Day & HL, DY & & & \\
\hline Salmophasia balookee (Sykes) & HL, DY & $\mathrm{Ru}$ & $\mathrm{m}$ & NEY \\
\hline \multicolumn{5}{|l|}{ Esomus danricus Hamilton-Buchanan } \\
\hline \multicolumn{5}{|l|}{ Esomus thermoicos Valenciennes } \\
\hline Devario aequipinnatus (McClelland) & $\mathrm{HL}$ & $\mathrm{Ru}, \mathrm{PI}$ & $\mathrm{I}, \mathrm{m}, \mathrm{h}$ & KLD, ITK, VAM, KAR, NEY \\
\hline Devario malabaricus + (Jerdon) & $\mathrm{HL}$ & $\mathrm{Ru}, \mathrm{PI}$ & $\mathrm{I}, \mathrm{m}, \mathrm{h}$ & KLD, ITK, VAM, KAR, NEY \\
\hline Rasbora daniconius (Hamilton) & $\mathrm{HL}$ & $\mathrm{Ru}, \mathrm{PI}$ & $\mathrm{I}, \mathrm{m}, \mathrm{h}$ & KLD, ITK, VAM, KAR, NEY \\
\hline Amblypharyngodon melettinus (Valenciennes) & HL, DY & $\mathrm{Ru}$ & $\mathrm{I}, \mathrm{m}$ & NEY \\
\hline Amblypharyngodon microlepis (Bleeker) & $\mathrm{HL}$ & & & \\
\hline Barilius bakeri + Day & $\mathrm{HL}, \mathrm{EX}$ & $\mathrm{Ra}, \mathrm{Ru}$ & $\mathrm{m}, \mathrm{h}$ & KLD, ITK, VAM, KAR, NEY \\
\hline Barilius bendelisis Hamilton-Buchanan & $\mathrm{HL}$ & & & \\
\hline Barilius gatensis + Valenciennes & $\mathrm{HL}$ & & & \\
\hline Cyprinus carpio Linnaeus & - & $\mathrm{Pl}$ & $\mathrm{m}$ & KLD, NEY \\
\hline Ctenopharyngodon idella Valenciennes & - & & & \\
\hline Labeo dussumieri + Valenciennes & $\mathrm{HL}, \mathrm{EX}$ & & & \\
\hline Labeo rohita Hamilton-Buchanan & $\mathrm{HL}$ & & & \\
\hline Labeo calbasu Hamilton-Buchanan & $\mathrm{HL}$ & & & \\
\hline Tor malabaricus + (Jerdon) & HL, OF, DY, EX & $\mathrm{PI}$ & $\mathrm{m}, \mathrm{h}$ & KLD, VAM, KAR, NEY \\
\hline Catla catla Valenciennes & - & & & \\
\hline Cirrhinus mrigala Hamilton-Buchanan & - & & & \\
\hline Garra mcclellandi +, RE (Jerdon) & HL, DY, EX & $\mathrm{Ra}, \mathrm{Ru}$ & $\mathrm{h}$ & NEY \\
\hline Garra mullya (Sykes) & $\mathrm{HL}, \mathrm{DY}, \mathrm{EX}$ & $\mathrm{Ra}, \mathrm{Ru}, \mathrm{PI}, \mathrm{Ri}$ & $\mathrm{I}, \mathrm{m}, \mathrm{h}$ & KLD, ITK, VAM, KAR, NEY \\
\hline Garra hughi +, RE Silas & $\mathrm{HL}$ & $\mathrm{Ra}, \mathrm{Ru}, \mathrm{Pl}, \mathrm{Ri}$ & $\mathrm{h}$ & KLD, VAM, NEY \\
\hline Garra surendranathanii Shaji, Arun \& Easa & $\mathrm{HL}$ & & & \\
\hline Horalabiosa joshuai Silas & $\mathrm{HL}, \mathrm{EX}$ & & & \\
\hline Hypselobarbus curmuca + (Hamilton) & $\mathrm{HL}, \mathrm{OF}, \mathrm{DY}, \mathrm{EX}, \mathrm{IN}$ & $\mathrm{Ru}, \mathrm{PI}$ & $\mathrm{m}, \mathrm{h}$ & KLD, ITK, VAM, KAR, NEY \\
\hline Hypselobarbus kolus + (Sykes) & HL, DY & $\mathrm{Ru}, \mathrm{PI}$ & $\mathrm{m}$ & KLD \\
\hline Hypselobarbus kurali ${ }^{+}$Menon \& Rema Devi & $\mathrm{HL}, \mathrm{DY}$ & $\mathrm{Ru}, \mathrm{PI}$ & $\mathrm{m}$ & KLD \\
\hline Osteobrama bakeri + Day & $\mathrm{HL}, \mathrm{DY}, \mathrm{IN}$ & $\mathrm{Ru}, \mathrm{PI}$ & $\mathrm{m}$ & KLD \\
\hline Puntius arulius Jerdon & $\mathrm{HL}$ & & & \\
\hline Puntius bimaculatus (Bleeker) & HL, DY, IN & & & \\
\hline Barbodes carnaticus ${ }^{+}$(Jerdon) & $\mathrm{HL}$ & & & \\
\hline Puntius chola Hamilton-Buchanan & $\mathrm{HL}, \mathrm{DY}, \mathrm{IN}$ & & & \\
\hline Puntius conchonius Hamilton-Buchanan & $\mathrm{HL}, \mathrm{DY}, \mathrm{IN}$ & & & \\
\hline Puntius denisonii + Day & HL, DY, OF & & & \\
\hline Puntius dorsalis (Jerdon) & $\mathrm{HL}, \mathrm{DY}$ & $\mathrm{Ru}, \mathrm{PI}$ & $\mathrm{m}, \mathrm{h}$ & KLD, ITK, VAM, NEY \\
\hline Puntius exclamatio ${ }^{+}$, ASH Pethiyagoda \& Kottelat & HL, EX, DY & $\mathrm{Ru}, \mathrm{PI}$ & $\mathrm{m}$ & KLD \\
\hline
\end{tabular}




\begin{tabular}{|c|c|c|c|c|}
\hline Species & Threats & $\begin{array}{c}\text { Preferred } \\
\text { Habitat }\end{array}$ & $\begin{array}{c}\text { Elevation } \\
\text { Range }\end{array}$ & Occurrence in Rivers \\
\hline Puntius fasciatus ${ }^{+}$(Jerdon) & HL, DY & $\mathrm{Ru}, \mathrm{Pl}, \mathrm{Ri}$ & $\mathrm{m}, \mathrm{h}$ & KLD, VAM, KAR, NEY \\
\hline Puntius filamentosus (Valenciennes) & HL, DY, IN & $\mathrm{Ru}, \mathrm{PI}$ & $\mathrm{m}$ & KLD, ITK, VAM, KAR, NEY \\
\hline Puntius undescribed ${ }^{+}, \mathrm{ASH}$ & $\mathrm{HL}$ & $\mathrm{Ru}, \mathrm{PI}$ & $\mathrm{m}$ & ITK \\
\hline Hypselobarbus jerdoni RE (Day) & HL, EX, DY & $\mathrm{Ru}, \mathrm{PI}$ & $\mathrm{m}$ & KLD \\
\hline Puntius mahecola +, RE (Valenciennes) & $\mathrm{HL}, \mathrm{IN}$ & $\mathrm{Ru}, \mathrm{PI}$ & $\mathrm{m}$ & KLD, ITK, VAM, KAR, NEY \\
\hline Puntius parrah Day & $\mathrm{HL}$ & $\mathrm{Ru}, \mathrm{PI}$ & $\mathrm{m}$ & KAR \\
\hline \multicolumn{5}{|l|}{ Puntius narayani ${ }^{+}$(Hora) } \\
\hline Puntius sarana subnasutus ${ }^{+}$Valenciennes & $\mathrm{HL}, \mathrm{OF}, \mathrm{IN}, \mathrm{DY}$ & $\mathrm{Ru}, \mathrm{PI}$ & $\mathrm{I}, \mathrm{m}$ & KLD, ITK, NEY \\
\hline Puntius tambraparniei ${ }^{+}$Silas & $\mathrm{HL}$ & & & \\
\hline Puntius ticto Hamilton-Buchanan & HL, EX, DY, IN & Ru, PI, Ri & $\mathrm{m}$ & KLD, ITK, KAR, NEY \\
\hline Puntius vittatus Day & $\mathrm{HL}$ & & & \\
\hline \multicolumn{5}{|l|}{ Gobiidae } \\
\hline Sicyopterus griseus Day & $\mathrm{HL}$ & $\mathrm{Ru}$ & $\mathrm{I}, \mathrm{m}$ & KAR \\
\hline Awaous gutum Hamilton-Buchanan & $\mathrm{HL}$ & $\mathrm{Ru}$ & $\mathrm{I}, \mathrm{m}$ & KAR \\
\hline Glossogobius giuris Hamilton-Buchanan & HL, DY, IN & $\mathrm{Ru}$ & $\mathrm{I}, \mathrm{m}$ & KLD, ITK, VAM, KAR \\
\hline \multicolumn{5}{|l|}{ Hemiramphidae } \\
\hline Hyporamphus limbatus Valenciennes & $\mathrm{HL}$ & $\mathrm{Ru}, \mathrm{PI}$ & I & KLD \\
\hline \multicolumn{5}{|l|}{ Mastacembelidae } \\
\hline Mastacembelus armatus (Lacepede) & HL, OF, DY, IN & $\mathrm{Ru}, \mathrm{Pl}, \mathrm{Ri}$ & $\mathrm{I}, \mathrm{m}, \mathrm{h}$ & KLD, NEY \\
\hline Macrognathus guentheri (Day) & HL, DY & & & \\
\hline \multicolumn{5}{|l|}{ Nandidae } \\
\hline Pristolepis marginata + Jerdon & HL, DY & $\mathrm{Ru}, \mathrm{PI}$ & $\mathrm{I}, \mathrm{m}$ & KLD, NEY \\
\hline \multicolumn{5}{|l|}{ Notopteridae } \\
\hline Notopterus notopterus Pallas & $\mathrm{HL}$ & & & \\
\hline \multicolumn{5}{|l|}{ Osphronemidae } \\
\hline Pseudosphronemus cupanus (Cuvier) & $\mathrm{HL}, \mathrm{DY}$ & & & \\
\hline \multicolumn{5}{|l|}{ Siluridae } \\
\hline Ompok bimaculatus (Bloch) & HL, DY & $\mathrm{Ru}, \mathrm{PI}$ & $\mathrm{m}, \mathrm{h}$ & NEY \\
\hline Ompok malabaricus + (Valenciennes) & HL, DY, EX & $\mathrm{Ru}, \mathrm{PI}$ & $\mathrm{m}, \mathrm{h}$ & NEY, KLD \\
\hline Wallago attu Bloch \& Schneider & HL, DY, OF & & & \\
\hline \multicolumn{5}{|l|}{ Sisoridae } \\
\hline Glyptothorax annandalei Hora & $\mathrm{HL}$ & & & \\
\hline Glyptothorax madraspatanus + Day & $\mathrm{HL}$ & & & \\
\hline \multicolumn{5}{|l|}{ Synbranchidae } \\
\hline Monopterus fossorius Nair & HL, OF, DY & & & \\
\hline Microphis cuncalus Hamilton-Buchanan & $\mathrm{HL}$ & & & \\
\hline \multicolumn{5}{|l|}{ Tetraodontidae } \\
\hline Carinotetraodon travancoricus ${ }^{+}$Hora \& Nair & $\mathrm{HL}, \mathrm{OF}$ & & & \\
\hline
\end{tabular}

Author names in brackets indicate redescriptions. Rivers: KLD - Kallada; ITK - Ithikkara; VAM - Vamanapuram; KAR - Karamana; NEY - Neyyar. PA Protected Area; NPA - Non-Protected Area. Elevation range: I - low (0-30 m); m - mid (30-200 m); h - high (200-1800 m). RE - Range extension to the Ashambu Hills Landscape; ^ - Taxonomy following new molecular study showing that the Indian species of Giant Snakehead; previously C. micropeltes should be treated as a distinct species C. diplogramma (Adamson et al. 2010). Endemism: ${ }^{+}-$Western Ghats; ${ }^{\text {ASH }}-$ Ashambu Hills. Preferred Habitat: Ru - Run; Ri - Riffle; Ra - Rapid; PI - Pool. Threats: HL - Habitat Loss; DY - Dynamite Fishing; OF - Overfishing; EX - Exotic species; IN - Industrial Pollution. 

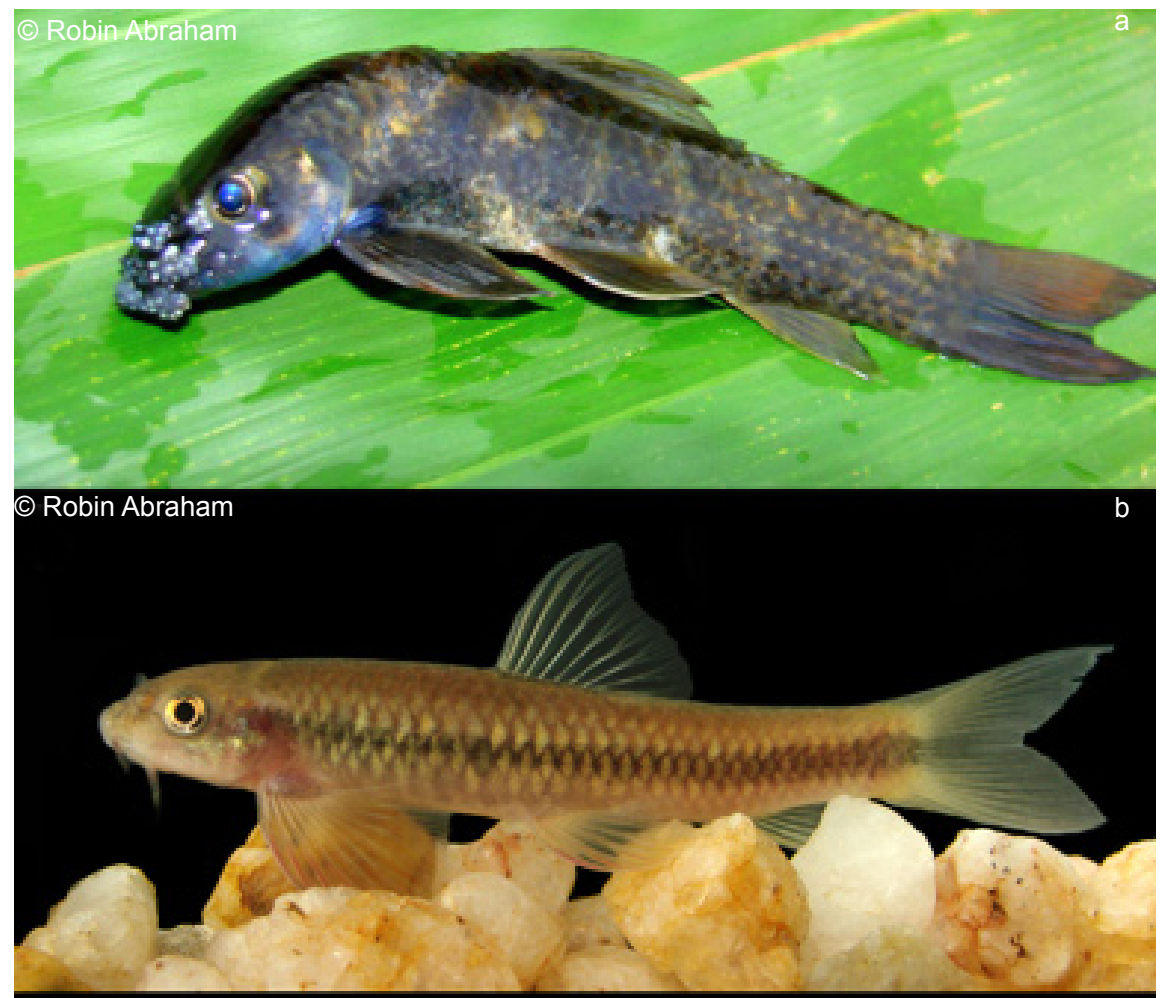

(อ) A. Bijukumar/edited by Robin Abraham
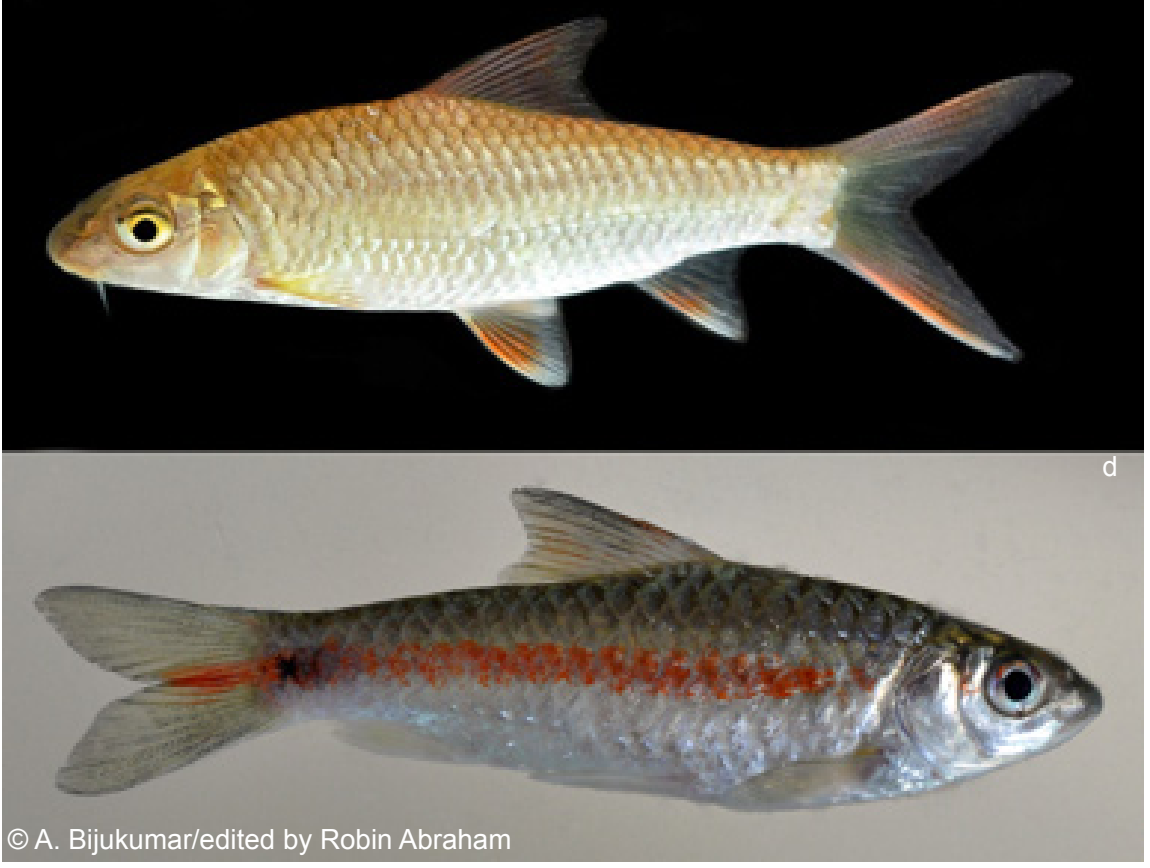

Image 1. Species whose range extensions have been recorded in the study. (Images not to scale) a - Garra mcclellandi

b - Garra hughi

c - Hypselobarbus jerdoni d - Puntius mahecola (male).

species. Species richness data were collected. We also opportunistically collected these data from local fishermen fishing at the same locations. Fish species were identified with the aid of taxonomic keys and field guides (Jayaram 1981, 2010; Easa \& Shaji 2003). Information on threats to and ecology of species was also collected based on observation, measurements of stream-related ecological covariates and semistructured interviews with local key-informants. 


\section{RESULTS}

A checklist of 103 freshwater fish species for this region was prepared using information from available literature and our sampling. The total number of species sampled by us was 58 , belonging to 35 genera and 16 families (Table 1). Of these, 25 species were endemic to the Western Ghats. Four range extensions to southern Kerala were recorded, viz. Garra mcclellandi, Garra hughi, Puntius mahecola and Hypselobarbus jerdoni. Garra mcclellandi was recorded in the Neyyar Wildlife Sanctuary. Garra hughi has been recorded in our study, from the higher elevations (above 900m) of the Shendurney Wildlife Sanctuary, Palode Reserve Forest and the Neyyar Wildlife Sanctuary (Fig. 1, Images 1-4). Hypselobarbus jerdoni is a new record for the Kallada River with in the Shendurney Wildlife Sanctuary and the Kulathupuzha River, a tributary of the Kallada in Kulathupuzha Reserve Forest. This now forms the southernmost record for this species. Puntius mahecola was collected from all five sampled rivers.

Sand-mining was found to be the most significant threat to the fish fauna, followed by dynamite fishing. Important, but rare indigenous food fishes such as Tor malabaricus were particularly threatened by dynamite fishing and the increased presence of exotic species such as Cyprinus carpio and Oreochromis mossambicus introduced in reservoirs and lowland areas. We observed niche overlap between exotic and indigenous species, and in some cases, (e.g. Cyprinus carpio and Tor malabaricus), exclusion of local species by exotic ones.

\section{DISCUSSION}

The present paper provides an updated checklist with the latest taxonomic revisions and range extensions for five river basins of the Ashambu Hills landscape. Studies in this region over the last five decades, from Silas (1951) to Thomas (2004) are restricted in scope, with incomplete coverage of rivers and streams across the elevation gradient of the Agasthyamalai ranges and a focus on particular taxonomic groups. We have made the best use of sporadic prior information on fish fauna in developing this checklist, and hope it will serve as a guide to policy makers, managers and conservationists. The range extensions that we report here underline the need for more intensive surveys across this region.

Garra mcclellandi was recorded earlier from the upper reaches of the Kaveri basin, the Nilgiris and Periyar Lake (Gopi 2000) and the current record of this species from Neyyar is the southward extension of this species. The type locality of G. hughi is the Anamalai Hills, with distribution including the Cardomon and Palani Hills and northern and central rivers of Kerala, and the present report confirms its presence throughout the higher reaches of southern Kerala, up to the southernmost river, Neyyar. However, G. hughi had been recently recorded in the Kallar River of Palode Reserve Forest (Johnson \& Arunachalam 2009). According to Jayaram (2010), Hypselobarbus jerdoni is distributed in the Deccan along the Western Ghats down south to the Anamalai Hills, and its southern record was previously from the Chalakkudy River in Kerala (Gopi 2000). The present record confirms its presence further south to the Kallada River in the Ashambu Hills. Pethiyagoda \& Kottelat (2005b) considered Puntius mahecola as a valid species and considered P. amphibius as its synonym. These authors re-described the species, with specimens collected from the Kallada River, sampled by us as well. The descriptions of the specimens collected by us were found to be in perfect taxonomic agreement with Pethiyagoda \& Kottelat (2005a,b) and we record the presence of this species in all the rivers sampled by us. The earlier reports of $P$. mahecola from the Western Ghats, which were probably female specimens of $P$. filamentosus, thus remain to be critically analysed.

We identified sand-mining and dynamite fishing to be the most destructive threats to freshwater fishes of this area. These practices seem to have caused severe habitat destruction and declines of rare substratedwelling loach fishes, and many important native food fishes. An example of this is Tor malabaricus, the Malabar Mahseer, which was reported to have been facing extreme population decline across the landscape, mainly attributed to dynamite-fishing. We mostly obtained this species from within protected areas, where dynamite-fishing was absent or negligible. Pollution, dumping of acidic wastes from rubber plantations and introduction of invasive exotic food fishes into dam reservoirs and lowland river areas were the other most critical threats. 
This broad-scale survey and sampling provides basic data for occurrence of fish species across the land use gradient in the region, for further targeted sampling to compare these different areas for their contribution to fish conservation, while assessing the magnitude of threats from existing practices (direct and indirect). Our paper thus provides the first step for detailed research on the freshwater fish fauna of the west-flowing rivers of the Ashambu Hills landscape, mainly with regards to taxonomic, ecological and conservation studies.

The conservation approaches suggested in this landscape include strict control over sand mining and unscientific fishing practices such as dynamiting and poisoning, the formation of river sanctuaries outside existing protected areas, construction of fish ladders in dams, in situ and ex situ conservation strategies (with the consideration that fish are also part of Indian wildlife), controlling pollution, and minimizing the threats posed by increasing numbers and diversity of exotic fish species.

\section{REFERENCES}

Adamson, E.A.S., D.A. Hurwood \& P.B. Mather (2010). A reappraisal of the evolution of Asian snakehead fishes (Pisces, Channidae) using molecular data from multiple genes and fossil calibration. Molecular Phylogenetics and Evolution 56(2): 707-717.

Arunachalam, M. (2000). Assemblage structure of stream fishes in the Western Ghats (India). Hydrobiologia 430: $1-31$.

Bhat, A. (2003). Diversity and composition of freshwater fishes in river systems of central Western Ghats, India. Environmental Biology of Fishes 68: 25-38.

Bhat, A. (2004). Patterns in the distribution of freshwater fishes in rivers of central Western Ghats, India and their associations with environmental gradients. Hydrobiologia 529: 83-97.

Biju, C.R., K.R. Thomas \& C.R. Ajithkumar (2000). Ecology of hill streams of Western Ghats with special reference to fish communities. Final Report. Bombay Natural History Society, Mumbai, India, 203pp.

Bossuyt, F., M. Meegaskumbura, N. Beenaerts, D.J. Gower, R. Pethiyagoda, K. Roelants, A. Mannaert, M. Wilkinson, M.M. Bahir, K. Manamendra-Arachchi, P.K.L. Ng, C.J. Schneider, O.V. Oommen \& M.C. Milinkovitch (2004). Local endemism within the Western Ghats-Sri Lanka biodiversity hotspot. Science 306: 479.

Basak, P., E.J. James \& M.D. Nandeshwar (1995). Water Atlas of Kerala. Central Water Resources Development and
Management Institute, Calicut, Kerala, India, 82pp.

Cherian, P.T., K.R. Devi, T.J. Indra, M.B. Raghunathan \& V.M.S. Kumar (2001). On the ichthyofauna of Trivandrum District, Kerala, India. Records of the Zoological Survey of India 99(1-4): 95-110.

Dahanukar, N., R. Raut \& A. Bhat (2004). Distribution, endemism and threat status of freshwater fishes in the Western Ghats of India. Journal of Biogeography 31: 123136.

Daniels, R.J.R. (2002). Freshwater fishes of Peninsular India. Universities Press, Hyderabad, 287pp.

Devi, K.R, T.J. Indra, \& K.G. Emiliyamma (1996). On the fish collections from Kerala deposited in the Southern Regional Station, Zoological Survey of India, by NRM, Stockholm. Records of the Zoological Survey of India 95 (3-4): 129-146.

Devi, K.R, T.J. Indra, M.B. Raghunathan \& M.S. Ravichandran (2005). Fish fauna of the Anamalai hill ranges, Western Ghats, India. Zoos' Print Journal 20(3):1809-1811.

Easa, P.S. \& C.P. Shaji (2003). Biodiversity Documentation for Kerala-Part 8: Freshwater Fishes. KFRI Handbook No.17, Kerala Forest Research Institute, Peechi, Kerala, India, $10-35 \mathrm{pp}$.

Eschmeyer, W.N. \& J.D. Fong (2010). Species of fishes by family/subfamily. URL: <http://research.calacademy.org/ research/ichthyology/catalog/SpeciesByFamily.html>. Online Version. Accessed on 26 May 2010.

Gopi, K.C. (2000). Freshwater fishes of Kerala State. pp. 5676. In: Ponniah, A.G. \& A. Gopalakrishnan (eds.). Endemic Fish Diversity of Western Ghats. NBFGR-NATP, India.

IUCN (2010) IUCN Red List of Threatened Species. Version 2010.1. <http://www.iucnredlist.org>. Downloaded on 11 March 2010.

Jayaram, K.C. (1981). The Freshwater Fishes of India, Pakistan, Bangladesh, Burma and Sri Lanka - A Handbook. Zoological Survey of India, Kolkata, India, 475pp.

Jayaram, K.C. (1991). Revision of the Genus Puntius Hamilton. Records of the Zoological Survey of India Occasional Paper No. 135, Zoological Survey of India, Kolkata, India.

Jayaram, K.C. (2010). The Freshwater Fishes of the Indian Region. Narendra Publishing House, Delhi, 616pp.

Johnson, J.A. \& M. Arunachalam (2009). Diversity, distribution and assemblage structure of fishes in streams of southern Western Ghats, India. Journal of Threatened Taxa 1(10): 507-513.

Tekriwal, K.L. \& A.A. Rao (1999). Ornamental Aquarium Fish of India. Kingdom Books, United Kingdom, 144pp.

Martin, P., M.A. Haniffa \& M. Arunachalam (2000). Abundance and diversity of macroinvertebrates and fish in the Tamiraparani River, south India. Hydrobiologia 430: 59-75.

Menon, A.G.K. (1987). The Fauna of India and the Adjacent Countries - Pisces, Vol. IV. Teleostei-Cobitidae, Part I: Homalopteridae. Zoological Survey of India, Kolkata, 
India, 259pp.

Myers, N., R.A. Mittermier, C.G. Mittermier, G.A.B. Da Fonseca, \& J. Kent (2000). Biodiversity hotspots for conservation priorities. Nature 403: 853-858.

Nair, S.C. (1991). Southern Western Ghats. Indian National Trust for Art and Cultural Heritage (INTACH), New Delhi, India, pp. 15\&58.

Pethiyagoda, R. (1994). Threats to the indigenous freshwater fishes of Sri Lanka and remarks on their conservation. Hydrobiologia 285: 189-201.

Pethiyagoda, R. \& M. Kottelat (2005a). A review of the barbs of the Puntius filamentosus group (Teleostei: Cyprinidae) of southern India and Sri Lanka. The Raffles Bulletin of Zoology 12: 127-144.

Pethiyagoda, R. \& M. Kottelat (2005b). The identity of the South Indian Barb Puntius mahecola (Teleostei: Cyprinidae), The Raffles Bulletin of Zoology 12: 145-152.

Raagam, P.M. \& K.R. Devi (2004). An overview of the hill trouts (Barilius spp.) of the Indian region. Zoos' Print Journal 20(4): 1847-1849.

Raghavan, R., P.H. Anvar Ali \& G. Prasad (2007). Need for a comprehensive reassessment of the conservation status of critically endangered freshwater fishes of Kerala. Current Science 92: 721-723.

Raghavan, R., G. Prasad, P.H.A. Ali \& B. Pereira (2008). Fish fauna of Chalakudy River, part of Western Ghats biodiversity hotspot, Kerala, India: patterns of distribution, threats and conservation needs. Biodiversity and Conservation 17: 3119-3131.

Sheeba, S. (1999). Certain aspects of the ecology of the Ithikkara River. PhD Thesis. Mahatma Gandhi University, Kottayam, Kerala, India.

Silas E.G. (1951). Fishes from the High Range of Travancore. Journal of the Bombay Natural History Society 50: 323-330.

Singh, K. (1998). Handbook of Environment, Wildlife and Forest Protection Laws in India. Natraj Publishers, New Delhi, India, 467pp.

Sreekantha, M.D., D.K. Mesta., G.R. Rao, K.V. Gururaja \& T.V. Ramachandra (2007). Fish diversity in relation to landscape and vegetation in central Western Ghats, India. Current Science 92: 1592-1603.

Thomas, R.K. (2004). Habitat and distribution of hill-stream fishes of southern Kerala (South of Palghat Gap). PhD Thesis. Mahatma Gandhi University, Kottayam, Kerala, India.
Author Details: Robin KurIan Abraham is a conservation ecologist with a keen interest in freshwater ecology and biogeography, animal behavior and conservation. He has been involved in the study of river ecosystems of the southern Western Ghats for almost seven years now. NACHIKET KELKAR is a wildlife biologist and has studied river dolphins, green turtles and community ecology of fishes in freshwaters, estuaries, coral reefs and seagrass meadows. His main interests are in population ecology and statistical modeling. DR. A. BIJU KUMAR is a senior lecturer at department of Aquatic Biology and Fisheries, University of Kerala. His areas of specializations include biodiversity informatics, and taxonomy and ecology of aquatic life. He has authored 18 books, more than 50 research papers and over 200 popular articles.

Author Contribution: RKA headed the project, conducted fieldwork, co-ordinated funding, and compiled the species checklist from reviews of taxonomic literature. NK contributed to planning the research and sampling design, data organization and analysis, and writing. ABK guided the first two authors in species identification, taxonomic assessments of species sampled and also provided data from his fieldwork conducted in parallel, in the Ashambu Hills landscape.

Acknowledgements: We thank the Conservation Leadership Program for having provided funding support for the study, and the Kerala Forest Department for providing research permits and logistic support. We are grateful to Ajith Kumar, WCS-India, and Uma Ramakrishnan, National Centre for Biological Sciences, Bengaluru for their support throughout the study and to R. Rajesh, Chacko, Chandrankutty, Francis, Sukumaran and Thomas Ammavan, who helped conduct field work and provided logistic support. We are also grateful to C.P. Shaji, P.H. Anvar Ali, Rajeev Raghavan and Kurian Mathew Abraham who helped in confirming species identification. 